Проф. др Јован Делић

Универзитет у Београду

Филолошки факултет

821.1663.41.09 Андрић И. https://doi.org/10.18485/ai_andric.2018.ch1

\title{
ЗАШТО АНДРИЋ ДАНАС?
}

Овај рад скреће пажњу на бројне неурађене послове у проучавању Андрићеве књижевности и њене поетике. На примјеру Андрићеве лирике показује се шта је све превиђено и шта би ваљало урадити. Иво Андрић је још увијек недовољно проучен писац и остаје велики изазов не само српској науци о књижевности.

Кључне ријечи: лирика, есеј, приповијетка, роман, поетика, жанр, мијешање жанрова, цензура, традиција, оспоравање, вредновање, прошлост, вјечност, мисаоност, тамница, архетип, прогнани пјесник, мост, симбол, алегорија, побједа, пораз, херој, авантура.

Чему данас толики научни скупови о Андрићу?

Зар већ све о њему, од њега и око њега није ишчитано и проучено и зар Андрић данас није анахроничан писац, застарио и превазиђен: безмало је сваки његов текст усмјерен на разумијевање прошлости, а савременог човјека занимају садашњост и будућност? Прошлошћу се баве само ретроградни духови, говоре нам модерни европски просвјетитељи са свих страна. Нијесу ли Андрићеви романи сувише старински и традиционалистички и не одударају ли од главних књижевних токова XX вијека? Каквог смисла има писати хронике y XX вијеку, а каквог тек смисла има те анахронизме тумачити? И каквог тек смисла има бавити се Балканом, тим најзаосталијим и најпроблематичнијим дије- 
лом Европе? Један Високи Представник, чијој титули је већ иманентна иронија - као да му је титулу измислио Петар Кочић - наложио је да се печатом обиљеже странице Андрићевих дјела које се не би смјеле уводити у наставу. Андрићев институт би морао прибавити и чувати тако обиљежене примјерке Андрићевих дјела као доказ мудрости, културне ширине и доказ о бризи за просвјету и културу српског народа што ју је међународна заједница несебично показивала у XXI вијеку. Како се само обрукала Европа, цијела културна планета, на размеђи миленијума о саму срж српске културе - о Његоша, Вука, Иву Андрића! Не заборавимо јој то. Високи представник, са највећим признањима за свој ужасни посао, показао се као најмрачнији цензор, према коме су домаћи стаљинисти питома мачад.

Неки високообразовани и високопозиционирани Андрићеви сународници муслиманске вјероисповести непрестано понављају како је Иво Андрић нанио више зла Босни него све непријатељске војске кроз историју. Истина, не казују ко су и шта су за њих непријатељске војске, а вјероватно себе нипошто данас не виде као Андрићеве сународнике.

О Андрићу као пјеснику проблематично је говорити већ и зато што овај писац није допуштао прештампавање својих раних пјесничких књига Ex Ponto и Немири и да се клонио сваке субјективности и страшног првог лица једнине. Иво Андрић није пјесник нити је то икада био.

Ето, могло би се пробрати неколико приповиједака и о њима би се могло говорити. Три романа припадају анахроничном жанру хронике. Госйођица је традиционално деветнаестовјековно дјело који се бави прастаром темом тврдичлука, а Проклетиа авлија тешко да би бројем ријечи и страница задовољила елементар- 
ни захтјев романа - обимност и обухватност. Омер-й $а$ шу Лайаса писац није успио ни да заврши, а о незавршеној ствари не вриједи расправљати. Дакле, нема се шта ново и лијепо рећи о Андрићевим романима.

Андрић као есејиста готово да не постоји. То што је писао о Његошу као трагичном јунаку косовске мисли данас би га могло препоручити за Хаг, а ако је о Гоји и написао нешто да ваља, то би могло више занимати Шпанце и Каталонце него нас. Што би се нас Гоја тицао?

Ма колико ови приговори, питања и примједбе били иронично интонирани, па чак и апсурдни, нијесу ни ирелевантни ни измишљени. Они постоје и са њима се свакодневно сударамо. Зато се у овим пословима ствари морају увијек наново разматрати.

За почетак може бити занимљив један разговор између Иве Андрића и Меше Селимовића који ми је прије четири деценије испричао Рајко Петров Ного. Селимовић је питао:

- Зашто Ви, Иво, пишете само о прошлости?

Слиједио је кратак, афористичан и једноставан одговор у стилу Знакова йореg йуйа:

- Прошлост је оно што остаје.

Дубоко смо увјерени да је Рајко Петров Ного беспрекорно запамтио Андрићеву реченицу и да је она морала бити управо таква. Ко се год имало бавио историјом, ко год има мрву историјског осјећања о којем је писао Т. С. Елиот, мора знати да прошлост није само оно што је било па прошло, већ и оно што нешто значи у садашњости; што је живо и што је такорећи вјечно. Наравно, по људским мјерилима вјечности. Па кад Андрић каже да је прошлост оно што остаје, он изговара једну од најдубљих истина уопште, али и једну од најдубљих истина своје поетике. Пишући, дакле, о прошлости као оном што остаје, Андрић пише о прошлости која је жива и актуелна у садашњости - пише о вјечности. 
Ето зашто је прошлост - а то увијек значи жива прошлост - чиста драгоцјеност и зашто је одрицање од прошлости одрицање од памћења, односно од културе, од традиције, од идентитета и континуитета, од вјечности. Зато се поштоваоци Иве Андрића прошлости одрећи не могу, јер би остали без ичега. Зашто се Андрићев народ не смије, не може и неће одрећи ни прошлости, ни Његоша, ни Вука, ни Андрића, јер би се одрекао себе.

О Иви Андрићу као скривеном пјеснику и о Андрићу као пјеснику с бодљом у срцу већ је писано. Питање које желимо да поставимо није нимало метафорично: Да ли је проучена Андрићева лирика и како је данас ваља цијенити: Ex Ponto, Немири, Шйа санам и ийа ми се gоіађа и све оно што обухвата појам лирика? Да ли су Знакови $\bar{u} о p e g \bar{u} y \bar{u} a$ лирика? Наравно да јесу и да припадају самом врху српске рефлексивне лирике. Они су примјер згуснутог, кондензованог лирског израза, најчешће осјенченог меланхолијом. Мисао је прожета осјећањем и нуди један онеобичен доживљај свијета. Да ли је то све проучено, сагледано у времену и ван времена?

Дубоко смо увјерени да Иво Андрић-пјесник заслужује ново пажљиво читање, па чак и нову књигу. Без књиге Ex Ponto, без тамничког искуства и прогонства по манастирима, не би било ни Проклетие авлије, ни фратарских прича, на фра Петра. Најдубље српске странице о тамници и тамничком искуству, али и о ћутању и приповиједању, зачеле су се са драгоцјеном књигом Ex Ponto. А те странице са Проклейом авлијом досежу сам врх свјетске књижевности.

Тамница и Ex Ponto, односно Овидије као прогна-

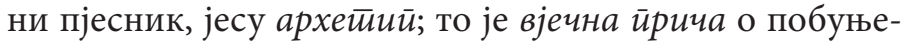
ном, утамниченом и прогнаном пјеснику. Ту је, ето, и саgашюос $\bar{u}$ призвала прошлост и вјечност, и постала је 
gио тие вјечностии. „Високо укочено Небо“ и „тврда немилосрдна Земља“ пратиће Андрићев доживљај свијета од Ex Ponta, преко приповиједака до краја живота.

Лирика су, дакле, и Ex Ponto, и Немири, и пјесме, и кратке прозне форме; лирика је нераскидиво повезана с најбољим и најдубљим Андрићевим прозним страницама.

У Ex Pontu се види како се понекад старе и овјештале, „отрцане“ истине згушњавају и добијају нова значења; како добра, стара општа мјеста постају вјечне истине. Ево једног цитата из Ex Ponta:

„Има истина које су старе, свагдање и отрцане дугим понављањем, али кад те истине сину човеку пред очима неказиване и ненаглашаване, него оцртане на шутњи једног страховитог часа, одигране међу живим људима, тада те старе овештале истине добијају нов и страховит лик и живе у gуши као вјечна болна мисао.“

Вјечна, болна мисао - није ли ту већ само Андрићево срце, на почетку, у Ex Pontu.

И није ли ово рецепт како настаје Андрићева кратка, лирска мисаона форма; како настају и његови Знакови ӣopeg йуйа.

Та ризница мисаоне, густе лирике, та форма која је сажела цијеле есеје у један мисаоно пренапрегнут и емотивно презасићен пасус, највише два - то су Знако-

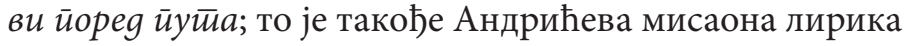
која је, ево, у присној вези с Ex Pontom и једним фрагментом из њега.

Немири су ризница Андрићевих симбола и опсесија: Немир од вијека, Немир дана, Брегови.

Широк је распон и велика дубина пјесникових немира. Андрић говори о борби човјека са Богом као о вјечној борби; као о старом човјековом боју „на који нас Бог позива тајном“: 
„А сваки жив човјек бори се с Богом, један дуље а други краће; и сваки подлегне.“

Слабост људских руку и тврд сан Господа оно је што спаја Андрићев „Немир вијека“ са библијском традицијом и Псалмима Давияовим:

„Како су слабе људске руке и како тврдо може да спава Бог.“

Човјек и Бог - два вјечна и неједнака противника и савезника.

Пјеснику, писцу мудрацу који је на свијет гледао са становишта вјечности, дневне побједе, ма како историјске биле, нужно морају бити привид. Пјесник је „изнад побједа“, јер је прича о побједи у основи лаж о побједи:

„Јер шта су друго данашње побједе него сутрашњи порази? У очима човјека самца нема добивених ни изгубљених битака, него у свим ратовима једнако: добивеним као и изгубљеним, једнако поражено човечанство.“

Андрића је увијек ужасавало урлање о побједи људи ниска чела и крвавих очију, јер истина са неког дубљег становишта изгледа страшније и безнадније:

„Све је то само кратак ружан сан, тај говор о побједама. Нема пораза ни побједа него увијек и свуда, код поражених једнако као и код побједника, напаћен и понижен човјек.“

Андрић је врло рано постао мајстор параболе и алегорије; он је алегорији вратио у симболизму изгубљени сјај.

Тему побједа и побједника наставља његова „Прича из Јапана“ која износи цио један пјеснички програм у писму пјесника Мори Ипоа, који не може да учествује у власти као што је учествовао у борби против царице Ау-Унг: 
„Мори Ипо поздравља, на растанку, другове своје, завјеренике!

Благодарим вам, другови моји, на заједничкој патњи и вјери и побједи и молим вас да ми опростите што не могу да с вама дијелим и власт као што сам дијелио борбу. Али пјесници су - противно од других људи - вјерни само у невољи, а напуштају оне којима је добро. Ми, пјесници, смо за борбу рођени: страсни смо ловци, али од плијена не једемо. Танка је и невидљива преграда што ме дијели од вас, али зар није оштрица мача танка, па ипак је смртоносна; без штете по своју душу не бих могао преко ње до вас, јер ми подносимо све осим власти. Зато вас остављам другови завјереници, и идем да потражим има ли гдјегод која мисао која није остварена и која тежња што није извојевана. А ви владајте разборито и срећно, али дође ли икад на наше царство Седам Отока каква биједа и искушење и буде потребна борба и утјеха у борби, потражите ме, молим вас.“

Не заборавимо, ова прича, ова парабола, дио је пјесничке књиге Немири. Проза је постала поезија; алегоријска прича, парабола - лирска програмска пјесма у прози.

Није ли то Андрић дијелио погледе авангардних српских пјесника и може ли се српска авангарда озбиљно описати без Ива Андрића? Већ смо писали о односу Андрић - Црњански из тих година.

Овом циклусу о побједама припада и пјесма, или прича, „Победник“, о Давиду и Голијату, о којој смо већ писали и говорили.

Није нам познат, у свјетским размјерама, писац, умјетник уопште, који је створио таквог Давида, побједника над Голијатом, какав је Андрићев Давид.

Андрић пише из Давидове, унутрашње перспективе и открива сав ужас побједа и побједника. Нико 
као Андрић није открио како је мрачно у душама хероја, које њихов чин, њихов подвиг и побједа, надилази и надмашује.

А ова прича, ова пјесма, остала је мало позната и углавном непрочитана, иако је сам врх Андрићеве хибридне лирске приче, можда и зато што је међу пјесмама, у Лирици, објављена. Андрић се као пјесник мало чита, мало зна и много прећутно потцјењује, иако наши аргументи говоре супротно.

Брегови, којима је било окружено сироче из Вишеграда, постали су Андрићева опсесија, једнако као и завичајна вишеградска стаза. Они су „врхови земље на којима влада за нас далека и неразумљива хармонија елемената“. Они су слободни од Бога и од човјека:

„Бијела тишина до које се није спустио Бог и до које није досегао човјек.“

Њима се пјесник обраћа с дивљењем и поштовањем, као истинском земаљском напору да се досегне небо:

„Ви сте напор земље - једини вриједан - пут неба и висине.“

Мало ко тако живо и присно осјећа самоћу, бол и страх као Андрић, и то већ од Еx Ponta и Немира, и готово их нико тако не уздигне на ниво космичког принципа. Андрић види сјенку страха на морским таласима: „Сјенка страха лежи на валовима који долазе да се разбију.“

А ево шта је видио у једном вечерњем часу, у зраку, засићеном људском близином:

„(...) видио сам несвијест и осамљеност у којој живи, ради и троши се материја, и умире ћелија за ћелијом, без свјетла и сазнања, у проклетој самоћи и болу којим болује све што је створено, што живи и што се миче.“

Ваља видјети свијет; ваља умјети гледати и видјети. А Андрић је рано стекао преосјетљив унутрашњи поглед који види другачије од осталих, који онеобичава свијет: 
„(...) И свијету се отварају увијек нови дани као ране.

Мени од свега што сам видио пламте очи. Велик свијет. Велик терет и велик умор. Дубока ноћ. А човјек сам.“

На крају Немира, у њиховој поенти, открива се људско лице којим је Андрић увијек опсједнут и кога се није могао нагледати. Немири, дакле, призивају доцнија Лица и показују рану Андрићеву опсесију лицима:

„Иза свих мојих горких ријечи крије се, ипак, увијек льуско тице са својом желом за срећом."

Колики је Андрић мајстор у лирици и колико му није страна „заумна“ пјесма, види се из три катрена пјесме „Лили Лалауна“, испјеване од имена једне Гркиње, односно од слогова њенога имена којим је пјесма насловљена: пјесник је употребио у цијелој пјесми „без значења“ само три вокала (и, а, у) и два консонанта ( $л$ и н):

\section{Лили Лалауна}

Лала лула, луна лина

Ала луна лани лана

Ана лили ула ина

Нали илун лилиана

Лила ани ул улана

Лани лину ул нанула

Анали ни нина нана

Ила ала уна нула

Алауна лул ил лана

Алилана, лан, лу, ли, ла.

Налу нилу нуне нинала

Нала уна ан анила. 
Андрићу, дакле, није био стран језички и пјеснички експеримент, а испјевао је пјесму комбинацијом свега пет гласова!

Андрић је вјероватно написао најљепше пјесничке редове о меланхолији и меланхолицима, поредивши их са јасикама: они су као и јасике; трепере када остало дрвеће мирује. Меланхолија је његов најучесталији лирски мотив, којем би вриједило посветити посебан рад. Зато се овдје њиме нећемо детаљније бавити.

Највећа човјекова утјеха на земљи долази од мисли. Нико толико не слави мисао колико Андрић. Та утјеха од мисли божанског је поријекла. Њу Бог шаље „као благу муњу“ и она је „највиши од свих дарова / небеских крајева које не познајемо, / а ни сенка јој није / највећа земаљска срећа“. Захваљујући том небеском и божанском дару, коме ни сјенка није „највећа земаљска срећа“, сиромашак човјек, „оличење сваке замаљске патње“, уздиже се изнад облака и „царује над свим хармонијама / ношен / утјехом која долази од мисли“ (15. XII 1922). Таква је моћ „утјехе од мисли“. Мало је ко у славу мисли и „утјехе од мисли“ тако запјевао. Као да је ова Андрићева пјесма полемички усмјерена на истоимену Ракићеву. Судећи по Знаковима йореg йуйа, ризници Андрићевих мисли, Бог му је у погледу ове утјехе био веома наклоњен.

Одазивајући се позиву да напишем прилог за свечани зборник радова посвећен професорки народне књижевности из Новог Сада, др Марији Клеут, поводом њеног одласка у пензију, скренули смо пажњу на једну Андрићеву буіаритиииу, о којој, колико нам је познато, до тада није писано. Нећемо понављати анализу ове пјесме, али ћемо је, ипак, прокоментарисати.

У „Дјевојачкој пјесми“ Андрић је оживио бугарштицу у модерном пјевању, користећи њену ритамску 
флексибилност и блискост говорном ритму. Различите дужине стихова, спорадична рима, коришћење туђега гласа и смисао за поенту приближавају форму бугарштице модерном слободном стиху и Иво Андрић је посегао за експериментом, ријетким у модерној српској поезији. У пјесму су уткани и фолклорни жанрови клетве и заклетве.

Цијела пјесма, сем три уводне ријечи - сем првог полустиха - испјевана је дјевојачким гласом, у директном обраћању дјевојке „сестри вили“. Али и тај глас је двострук, из два времена. У њ је уплетено дјевојчино обраћање вољеном Маријану којим га је дјевојка некаg заклињала, и у том обраћању је поента: метафоре о пролазности љубавне ватре и дјевојачке љепоте и афористичко коришћење компаратива у функцији поређења. Пјесма је чак из 1933. године, када је Иво Андрић таман развршио пету деценију живота. Он се у овој пјесми показује као мајстор пастиша, познавања народних ритмова, али и зналац људске природе; мајстор уживљавања, способан да запјева из женске перспективе, и не једини пут:

$$
\begin{aligned}
& \text { Дјевојачка ӣјесма } \\
& \text { (као народна) }
\end{aligned}
$$

Дјевојка вилу преклињала:

- О вило, свијетла сестро вило, Тако не знала људског јада ни женске сузе удеснице, Кад видиш гором да пројезде кршне левенте, пусти момци, Заустави ми најмлађега, мајчина млада Маријана, Ал' не стрељај га, сестро вило, 
ни љутом стријелом ни погледом

Ни уроцима вилинскијем.

Само га питај гласовито,

Куд путе гази, младост троши?

Шта мисли са мном суђеницом,

Са мојим срцем осуђеним

и са животом узабраним?

Докле мисли путовати, царске градове освајати?

Нек ломи срце, нек казује и нек не жали мене младу,

Коме ли ће се привољети, мени, дјевојци ашиклији Ил' проклетом царском граду?

Ил' царском граду кога бије већ ево има три године, Са три стотине левената у камен му се претворили! Поздрави ми га, нек се сјети чим сам га некад заклињала, Шта сам му тада говорила: „У младости су брза крила, Очи су ватре кратка вјека, дјевојке цвијеће Ђурђевданско! А нема, болан Маријане, горчијега пића од растанка Ни црњег хљеба од самоће, ни теже смрти од чекања.“ Тако га зови и призивај, не би ли ми га домамила, Кунућ га мојим заклетвама, а твојим гласом вилинскијем. 
Из исте, женске, дјевојачке перспективе испјевана је, такође женским гласом и говором, тродјелна градацијска пјесма „Лепа млада жена говори“. Лепа млада жена би, прво, да је „вода текућица / У којој многи жеђу гасе“. Вода је метафора женског принципа, а овдје и израз жеље за усрећивањем многих. Вода гаси жеђ многима, али у њој је и способност очишћења, па ти многи, ти жедни љубавници, одлазе задовољни, чисти и умивени, али бескрајно срећни:

Да сам вода текућица

У којој многи жеђу гасе,

И сваки одлази задовољан, чист и умивен,

Са својом срећом јединственом

Којој на свету нема равне.

Али млада, лијепа жена већ у другој жељи хоће да је пиће силовито и да, у баханалијама, остварује најлуђе и најсмјелије жеље другарима по крчмама, па је женска љепота у својој жељи удружена с еротском деструкцијом:

Да сам пиће, силовито и радосно,

Које пију другари по крчмама,

Тражећ срећу у осмејку и заборав у певању.

Да им ја жеље остварујем, и најлуђе и најсмелије, Помамним шумом ноћних сати, густим димом теревенке.

Најзад, у градацијском климаксу, жеља љепотице досеже смрт - деструкција је потпуна. Љепотица би хтјела да је „отров, муњевит и непознат“: 
Да сам отров, муњевит и непознат, Пиће за оне који не могу Да сачекају залазак сунца, Да сечем живот у корену, брже од муње, Да мисли, бића и светове

Бришем нетрагом заборава.

Дотле, ето, сеже женска еротска деструкција, и то младе и лијепе жене - „да мисли, бића и светове“ брише „нетрагом заборава“.

Оваквог Андрића мало знамо, али овај и овакав Андрић је веома близак писцу „Аникиних времена“, па се разорни женски лик боље разумијева уз ову пјесму.

Андрић је доминантно мисаона природа, мудрац, контемплативац. Мисао и мисаоност су у коријену сваке Андрићеве књижевне замисли. Зато је дубоко у праву Иво Тартаља када види есеј у основу Андрићевог стваралаштва. Мисаоност и есејизација прожимају цјелокупно Андрићево књижевно дјело. Свака прича, сваки роман, па готово и свака пјесма оплемењени су мишљу и озрачени есејем.

Иво Андрић је написао два најбоља, најдубља и најљепша есеја у српској књижевности: „Његош као трагични јунак косовске мисли“ и „Разговор са Гојом“. Први га укорјењује у српску традицију; други показује пишчеву умјетничку универзалност и поетику. Андрићева бесједа о причи и причању сигурно је једна од најумнијих међу бесједама нобеловаца. То је сам врх српске есејистике и по мисаоној продорности и значењу, и по умјетничким дометима: „Разговор са Гојом“ је врхунска умјетничка проза.

Пишући о Његошу и Вуку - а о њима је убједљиво највише писао; о Његошу чак десет радова - Андрић је 
успоставио три главна традицијска стуба новије српске књижевности: Његош - Вук - Андрић. Та три традицијска стуба данас се покушавају изнутра минирати, као што је неки фелдбевел Бранковић минирао седми стуб ћуприје на Дрини.

У својим есејима о Његошу Андрић исказује и елементе своје поетике, и свој однос према Европи и свијету, а тај однос би се могао свести на став: пратити домете европске културе, али остати свој. Први услов сваког, па и књижевног опстанка, јесте бити вјеран своме језику, своме народу, својој традицији, а бити способан и спреман да будеш дио свијета и да примиш највише вриједности.

Да ли је кратки, програмски, поетски текст „Мостови“ есеј? Он је програмски у темељу „Моста на Жепи“ и романа На Дрини ћуйрија. У том кратком запису спојено је лирско, поетско, путописно и есејистичко. То је, како написа Иво Тартаља, „филозофска поема“.

Нема сумње, Иво Андрић је врхунски есејиста. О његовој есејистици је писано добро и системски, али није у довољној мјери освијетљена љепота Андрићевих есеја нити њихов значај у српском, јужнословенском и европском контексту.

Нико у српској књижевности није написао толико, уз то врхунских, приповиједака као Иво Андрић. Чак ни његове приповијетке нијесу довољно ишчитане нити интерпретиране, а да не говоримо о поетици Андрићевих приповиједака. Све то чека на ново читање, опис, интерпретацију и вредновање.

Посебно отворена тема су Андрићеви романи. Нетачна је тврдња да су три његова романа хронике; то сам писац никада није рекао. То је само, и само условно, Травничка хроника. Иво Тартаља је убједљиво показао како ваља читати и тумачити Проклет̄у авлију у 
контексту свјетске књижевности и у свијетлу Андрићеве поетике и естетике. Радован Вучковић је убједљив када се залаже за читање романа На Дрини ћуирија у контексту модерног европског романа. Госйођица није никакав деветнаестовјековни анахронизам, већ роман који користи филмске поступке и технику. Омер-йаша Лайас остаје загонетан својом недовршеношћу и изазов је тумачима.

Зрело је вријеме да се напише поетика Андрићевих романа: да се опишу ликови, развој сижеа, простор, вријеме, тематске и стилске доминанте, кључни умјетнички поступци. То није систематски урађено. Андрић има времена, али смо ми дужници.

Најзад, присиљени смо да одговарамо на глупости, на клевете и злонамјерне нападе. Најбољи одговор су, наравно, озбиљне студије, али понекад је важно указати на апсурдност и злонамјерност програмираних и синхронизованих оптужби.

Како је могућно аутора „Мостова“ оптуживати за мржњу? Једна лична, биографска ситница: Иво Андрић је у два маха, из два дијела, поклонио цјелокупан износ своје Нобелове награде својој земљи и своме народу за књиге и библиотеке. Није људе раздвајао по вјери и нацији.

Иво Андрић је хвалио српску, и уопште југословенску књижевност послије Првог свјетског рата што је била лишена мржње. А за мржњу је било разлога.

Присјетимо се статуса муслиманских јунака у роману На Дрини ћуйрија: велики везир Мехмед-паша Соколовић је, као и везир Јусуф из приповијетке „Мост на Жепи“, градитељ мостова и носилац љубави према завичају. Хоџе Мутевелићи, а нарочито Алихоџа, чувари су вакуфа и носиоци највиших вриједности.

Већ смо писали о оној важној епизоди при крају романа у којој бегови разговарају са Алихоџом о намје- 
ри да преузму вођство над шуцкорима од Хусе Кокошаpa, коме је срамотна болест откинула пола носа. Алихоџа им савјетује да то нипошто не чине уколико неће да се од бегова преобразе у кокошаре. Ни та дилема није била само дилема дана, већ - као и свака озбиљна издаја - питање вјечности. То се данас јасно види.

Посебно је драгоцјен статус Ћамила у Проклетиој авлији. Ћамил значи Савршени, и то би људи који клевећу Андрића морали знати. Али мржњи знање није потребно.

А какав тек статус има Хамдибег Тескереџић у Травничкој хроници! Он уоквирује роман и његов глас је носилац алегоријског значења романа. Његова позиција је апсолутно повлашћена у роману.

Циљ овога рада је био да покаже колико је неопходно говорити о Андрићу проучавајући Андрића; колико је неопходно држати ниво у том говору.

На примјеру Андрићеве лирике, као најмање проученог сегмента његовога опуса, показали смо какве све вриједности превиђамо, па и потцјењујемо, код писца који нас је у једном тренутку учинио центром свијета. Андрићева лирика, и њена поетика, заслужује посебну књигу. Ако је тако с лириком, како је тек са осталим дјеловима његовог монументалног опуса.

Што се нас тиче - остајемо да му служимо проучавајући га. 
Јован Делић

\title{
ЗАШТО АНДРИЋ ДАНАС?
}

\begin{abstract}
Резиме
Напоредо са бројним научним скуповима о дјелу Иве Андрића чују се и гласови сумње у оправданост таквих скупова, чак и гласови оспоравања вриједности Андрићевих дјела. Зато смо на примјеру Андрићеве лирике - најпотцјењенијем дијелу Андрићевог опуса - показали какве се вриједности превиђају у Андрићевој лирици и колико је непроучених питања и проблема. Потом се јасно вреднује Андрићева есејистика, истиче се значај и лирике и есејистике за разумијевање Андрићевог опуса у цјелини и наговјештава се колико је неурађених послова већ на нивоу интерпретације, вредновања и проучавања поетике Андрићевих дјела.

На крају рада се оспоравају оптужбе упућене Андрићу, а преко њега Вуку и Његошу, односно српској традицији, за негативан однос према муслиманима. Статус јунака у Андрићевим романима, и њихово значење, какви су Мехмед-паша Соколовић, хоџе Мутевелићи, а посебно Алихоџа, у роману На Дрини ћуйрија, Хамдибег Тескереџић у Травничкој хроници и Ћамил (Савршени) у Проклейој авлији обесмишљавају такве оптужбе.
\end{abstract}

Jovan Delić

\section{WHY ANDRIĆ TODAY?}

\section{Summary}

In addition to numerous scientific meetings on the work of Ivo Andrić, voices of suspicion about the justification of such conferences are heard, even voices of challenging the 
value of Andrićs works. That is why, on the example of Andrićs lyricism - the less esteemed part of Andrićs opus - we have shown what values are overlooked in Andrićs lyricism and how many questions and problems have not been scrutinised. Then, Andrićs essayistics are clearly valued, the significance of lyricism and essayistic for the understanding of Andrićs opus in general is emphasized, and it is indicated how many unmanaged jobs are already at the level of interpretation, evaluation and study of the poetics of Andrićs works.

At the end of the article, the charges against Andric are challenged, and through him against Vuk and Njegoš, i.e. the Serbian tradition, for a negative attitude towards Muslims. The status of the hero in Andrićs novels, and their meaning, such as Mehmed-paša Sokolović, the hodjas Mutevelićs, and especially Alihodja, in the novel The Bridge on the Drina (Na Drini ćuprija), Hamdibeg Teskeredžić in the Travnik Chronicle (Tranička hronika) and Ćamil (Perfect) in The Damned Yard (Prokleta avlija), they refute such accusations. 